\title{
Collective Management System of Internet Copyright under the Principle of Balance of Interests
}

\author{
Ning $\operatorname{Han}^{1}$ \\ ${ }^{1}$ School of Law, Jinan University, Jinan, China \\ Correspondence: Ning Han, School of Law, Jinan University, Jinan, China. E-mail: sl_hann@ujn.edu.cn
}

Received: March 29, 2012

Accepted: April 27, 2012 Published: July 1, 2012

doi:10.5539/ass.v8n8p177

URL: http://dx.doi.org/10.5539/ass.v8n8p177

Research achievement of the humanity and social science research project in institutions of higher learning in Shandong Province in 2009 "Strategic Research of Intellectual Property Protection in Institutions of Higher Learning”, Item NO: J09WK64; periodical achievement of the scientific research foundation project of Jinan University in 2011 "Research of Infringement Act of Intellectual Property in the Internet Environment", Item NO: X1105.

\begin{abstract}
With acceleration of the progress of networking, realization and protection means of copyright can no longer suit with the developmental need of information technology. The principle of balance of interests is the core of intellectual property system and improvement of collective management system of copyright in the internet environment can economically and effectively guarantee realization of balance of interests.

Keywords: collective management of copyright, internet environment, balance of interests

\section{Copyright Collective Management Organizations}

Collective management system of copyright is a particular system in intellectual property protection system. So far, foreign copyright collective management organizations have had a history of more than two hundred years and the earliest copyright collective management organization was born in France as early as in the $18^{\text {th }}$ Century. This system was then gradually simulated by other European countries and other regions in the world. At the turning of the end of the $19^{\text {th }}$ Century and the beginning of the $20^{\text {th }}$ Century, a variety of collective management associations were set up all over the world to execute their collective management of works.
\end{abstract}

\subsection{Legislation on Collective Management of Copyright}

China has undergone a process of growing out of nothing in terms of legislation on collective management of copyright. "Copyright Law" that was issued in 1990 did not make any specification on the collective management of copyright. For the first time, "Implementing Regulations of the Copyright Law" in 1991 made relevant specifications on collective management of copyright and it was stipulated in Article 54 in the regulation that a copyright owner could execute his copyright by means of collective management. In 2001, principle provisions were made on collective management of copyright in amendment of "Copyright Law". For the first time, the legal status and property of collective management organizations were specified and collective management organizations were endowed with the right to execution in the name of these organizations and the function of litigation. In 2004, in pursuant to provisions of "Copyright Law", the State Council promulgated "Collective Management of Copyright" to make detailed specifications on specific business and supervision function of collective management organizations. However, considering the current legislation in China, specific use and operation of copyright collective management in the information network environment is seldom concerned, which will be a key issue in copyright collective management with popularization of the internet.

\subsection{Development and Status Quo of Copyright Collective Management Organizations}

By April in 2010, there had already been five copyright collective management organizations in mainland China, which were respectively Music Copyright Society of China, China Audio-Video Copyright Association, China Written Works Copyright Society, Images Copyright Society of China and China Film Copyright Association. 
In collective management of copyright of music works, Music Copyright Society of China (MCSC) is the first copyright collective management organization in China, which is a non-profit making institution that is special aimed to protect legal interests of composers, songwriters and other music copyright owners. According to "Implementing Regulations of the Copyright Law", the State Copyright Bureau set up the Remuneration Collection and Distribution Center for the Use of Copyright, which is an institution having the function of remuneration distribution for copyright collective management organizations. China Audio-Video Copyright Association (CAVCA) was approved by the State Copyright Bureau and was established on May 28, 2008. It is mainly responsible for collective management of audiovisual programs copyright and related rights. China Written Works Copyright Society (CWWCS) was launched together by 12 units that have concentrated copyright owners, such as, Chinese Writers Association, Development Research Center of the State Council and so on, and more than 500 copyright owners and was set up on October 24, 2008 in Beijing. It is mainly responsible for collective management of literary works copyright and related rights. Images Copyright Society of China (ICSC) is a copyright collective management organization that was launched by Chinese Photographers Society jointing multiple photography groups and almost one hundred well-known photographers and was set up on November 21,2008 in Beijing. It is mainly responsible for management of copyright and related rights of photography works. China Film Copyright Association (abbreviated as CFCA) was set up on April 16, 2010 in Beijing and its predecessor is "China Film Copyright Protection Association". Considering its property, CFCA is a copyright collective management organization that is converted from an industrial safeguarding organization and it is mainly responsible for collective management of copyright and related rights of copyright owners of film products. (Wang Jifa \& Li Gexia, 2011)

These five collective management organizations cover the major cultural fields of literary words, music, audio-video, photograph and film, etc., and serve as a bridge and bond for realization of ownership of property of copyright owners by means of collective management of copyright. Besides, this mode of copyright collective management also adds to security of copyright users and saves them from appeal of infringement, which, in turn, helps to balance interests of copyright owner and user.

\section{Legal Analysis of Implementing Copyright Collective Management System in the Internet Environment}

Authorized and entrusted by a lot of obligees of works, copyright collective management organizations are particularly engaged in management of copyright. They are able to throw a huge amount of investment, allocate professional personnel and cooperate with other institutions and organizations, which are investment behaviors that individual management is unable to proceed with. Considering the current network environment, it is quite important to strengthen collective management of copyright of works.

\subsection{Analysis of Necessity}

\subsubsection{Need of New Changes for Dissemination of Copyright of Works in the Internet Environment}

Network technique offers conditions for unlimited dissemination of works, while dissemination and use of works breaks through regional constraint of copyright and contributes to non-border of dissemination of works with copyright and spreading all over the world of users of network works. At the time when the dissemination speed of works is expedited and the scope is enlarged, the dissemination also goes beyond the sphere of control by authors. In the meantime, network technique makes the existence pattern of works simplified. Works can be freely uploaded and downloaded and a majority of network content is interactively stored, uploaded and downloaded without permission of the obligees. Once the works enter the network for circulation, any person may obtain them randomly and easily at any time and in any place. The highly developed reproduction technique causes authenticity and completeness of works unlikely to be determined, so it is necessary to strengthen construction of copyright collective management system in the internet environment.

\subsubsection{Collective Management of Copyright May More Effectively Realize Balance of Copyright}

Owing to rapid development and popularized use of network technique, enormous reform has been brought to utilization means and dissemination approach of works, with more extensive dissemination of works and broader space for collective management of copyright. In the internet environment, this basic principle of protecting authors and encouraging creation in "Copyright Law" has not had any change and pursuit of balance of rights is still the tenet and objective of legislation of copyright. As a matter of fact, collective management of copyright still does not lose its role as a bridge between the obligee and the user and it is able to more effectively adapt to requirement and features of network technique in the information network, provides convenience for communication and exchange between the users and obligees of the works and realizes balance of copyright. Owing to its role of communication, on one hand, collective management organizations may make full use of professional institutions and technical advantages to supervise online and keep track of any use of the works, 
develop the market of the works on behalf of the authors and attempt to realize all due rights of authors in a extensive and comprehensive way. On the other hand, collective management organizations also offer more comprehensive information about the authors and their works for the vast majority of users, which is convenient for the users to acquire the works they need in a shortcut way. (Duan Wei, 2006)

\subsection{Analysis of Rationality}

\subsubsection{Balancing Interests of Authors and the General Public}

Rationality of implementing collective management system of copyright in the internet environment lies in attaining a balance between interests of intellectual property owner and interests of the social general public in the dynamic process of production and circulation of intellectual products (Li Zhiyan, 2003). Copyright collective management organizations concentratively operate and manage the use permission and supervision of works through professionalized operation, which not only offers a means for the authors to guarantee their own rights and to disseminate their works, but also offers an approach to legally use the works for the general public. In the internet environment, quite a lot of works are concentrated together through the platform of collective management of copyright and an information market is set up between the authors and the general public, so the users may get access to the works they need in the market. Of course, this access is based on a legal approach, which not only ensures that the authors acquire economic profits by means of dissemination of works, but also helps the general public to get access to excellent works and finally promote improvement of spiritual and cultural quality.

\subsubsection{Realizing Optimum Distribution of Resources}

Considering literary and artistic creation of authors per se, neither the authors have any professional knowledge in management, nor could they throw too much time and energy to manage their works. Nevertheless, whether the economic value of the works can be realized has a direct effect on the enthusiasm of authors in creation. Copyright collective management organizations have rich experiences and what they are involved in a sort of routine and a huge batch of management work, which determines that their efficiency in dealing with transaction of copyright is high. Dissemination of works in the internet environment is not only wide in terms of scope, but also has a lot of users. Implementation of collective management may cut down on expenses of the transaction and economize the transactional costs to ensure the authors obtain more economic benefits.

\section{Developmental Trend of Copyright Collective Management Organizations in the Internet Environment}

The purpose of networking of collective management of copyright is to protect rights and interests of copyright owners, and, meanwhile, offers convenient and shortcut works authorization service for users of the works. Pursuit of balance of rights is the tenet and objective of legislation of "Copyright Law". Thus, copyright collective management organizations should, from beginning to end, be guided by this principle in the process of setting up an electronic management system, take full consideration of the demands of both users and copyright owners of the works, and start out from simple and intuitive use of the system and fully protecting rights and interests of copyright owners to organize and construct the network service platform and the website of the platform.

Works of copyright owners is the basic resource of copyright collective management and it should be convenient for copyright owners to be able to make a successful use of the platform to register their works in the process of constructing the electronic platform. At the same time, users of the works should acquire a convenient and shortcut approach for permission to use the works. If the objective need of the users of the works is ignored, efficiency of electronic management means will, to a large extent, be reduced.

\subsection{Problems Encountered by Copyright Collective Management in the Internet Environment}

In the internet environment, copyright works are disseminated within a global scope rapidly and widely by the digitalized means. Furthermore, the right content of copyright as a private exclusive right has had great changes and the traditional copyright collective management mode can no longer provide better protection.

\subsubsection{Changes of Functions of Copyright in the Internet Environment}

It is specified in "Copyright Law" and "Collective Management of Copyright", the rights that can be managed by copyright collective management organizations on behalf of copyright owners include the following six ones: right of performance, right of projection, right of broadcasting, rental right, right of reproduction, and right of dissemination through information network. From a realistic perspective, in the internet environment, the major dissemination mode of works is digitalization and networking. This sort of dissemination mode enables an individual to authorize personally within a certain scope so as to execute the functions of the traditional 
copyright management organizations. This sort of multi-mode management platform on the internet is both an opportunity and a challenge as for the copyright collective management organizations. Thus, it is more helpful to facilitate the collective management organizations to enhance their working efficiency and provide better service for copyright owners.

\subsubsection{Expedited Progress of Internalization of Copyright Collective Management}

Globalization of network decides that once the works are uploaded online, they can be used at any computer terminal across the world. Territoriality is a basic principle of the traditional copyright law, which proposes a new issue for multi-national protection of copyright. Under the framework of Berne Convention and TRIPs, works are under protection in all member countries. However, it is rarely possible for the copyright owners to take a complete control over the behaviors of using the works all over the world. In addition, litigation and claiming indemnity after discovery of an infringement also concerns different legal cultures and judicial systems in different countries. Thus, it is unlikely to control the use behaviors merely relying on the personal power of copyright owners. It is exactly multi-national coordination and protection of copyright owners that is the primary function of collective management organizations. In practice of the international copyright protection, collective management organization development acts as "mutual representation agreement" (Note 1) to enable copyright of foreign works to receive respect at home. Meanwhile, it also enables the works at home to get protection in the member countries of the agreement (Luo Xiangjing, 2009). Currently, all countries have begun to focus on the international cooperation of collective management of copyright. For instance, MCSC has already signed the mutual representation agreement with associations from more than thirty countries and regions and have listed data about members of the associations and the works into CAE directory (international authors, composers and publishers) and WWL (World Wide Licenses), so as to enable Chinese works to enter the international identification system. Once Chinese works are used overseas, their rights can be protected.

\subsection{Measures Taken to Improve Construction of Copyright Collective Management Organizations in the Internet Environment}

Today when dissemination through internet becomes increasingly developed, the traditional publishing industry has undergone serious attack and fulfillment of the economic interests of copyright owners, to a large extent, depends on their control over dissemination through network. Copyright collective management system is the optimum approach to reduce social transactional costs and is also an important mode to guarantee the core principle of balance of interests. Thus, it is of great economic significance to set up and improve copyright collective management system.

\subsubsection{Improvement of Legal Construction of Copyright Collective Management in the Internet Environment}

For the time being, the copyright collective management system in China is still at its initial stage and there have had detailed provisions as for collective management of copyright in the amended "Copyright Law" and the promulgated "Collective Management of Copyright". Nevertheless, compared with practice of collective management of copyright, there is still a gap and there still exist some disadvantages and problems. In the legislative work in the future, it is still required that the law make more detailed and feasible provisions on specific operation of copyright collective management organizations, especially collection and distribution of the using fee, which, without doubt, is a critical issue. The fee of using the works with collective management of copyright should be confirmed in accordance with the categories of the rights of different works on the basis of unified management by a comprehensive collective management organization.

\subsubsection{Expanding the Business Scope of Copyright Collective Management Organizations}

Today when copyright becomes networking, use of works often concerns about a variety of functions of copyright. Complying with diversification of the categories of works and their rights, the organization means of collective management should also present the feature of diversification. In this regard, those countries that are relatively mature in collective management of copyright have already had mature experiences. Some countries set up an association according to the categories of works or categories of rights, while some other countries set up a unified association that contains all creation fields. As for collective protection of internet copyright, a comprehensive organizational role is more prominent. In practice, some European countries have begun to attempt to offer the possibility of one-time authorization for users when comprehensive use of works (mainly those works with multiple copyrights, especially works with multiple copyrights in the internet environment) that belong to different copyright owners through the domestic "one-stop service" organizations. (Wang Ping, 2010) For example, collective management organizations in Germany join up together to develop a electronic clearing system for multi-media manufacturers and set up CMMVV multi-media clearing structure; Japanese copyright information service center also offers a database of copyright information in the multi-media field for its users 
(Luo Xiangjing, 2009). We are supposed to borrow these mature experiences and set up an effective approach to management of copyright on the internet platform.

\subsubsection{Strengthening Technical Measures to Protect Legal Interests of Copyright Owners}

The so-called technical measures refer to the facility, product or method actively used by copyright owners or related obligees to be able to effectively control their works that are under protection of the copyright law, provide effective protection on the rights of their works and prevent infringement upon their legal rights and interests. The copyright law in China has a specified principle on the right of technical measure, and mainly specifies from the perspective of infringement. Any behavior that intentionally avoids or damages the technical measures taken by the obligees to protect their copyright or any other right related with the copyright for their works and audio and video recording products belongs to an infringement behavior. As a matter of fact, it is ascertained that the copyright owners have the right to take technical measures to protect their works.

In addition, copyright owners may also consolidate the effect of copyright collective management by means of encrypting the management information. Copyright management information refers to the information about copyright of works and copyright owners of works that is attached by the copyright owners to the duplicated document of the works for protecting and managing their own works and that is disclosed when the works are disseminated to the general public. (Li Guangyu, 2008) At the time when the obligees authorize the copyright collective management organizations to perform related rights, they should also authorize the organizations with corresponding rights management information. The collective management organizations are obliged to offer part of relevant rights information about the works to the potential users of the works. In the meantime, at the time when the collective management organizations supervise use of works by users, they have the right to prohibit any behavior of deleting or modifying the rights management information.

\section{References}

Duan, Wei. (2006, October). On the Legal Protection of Copyright at the Age of Net. Hubei Education Press, $122-125$.

Li, Guangyu. (2008, March). Construction of the Protection System of the Copyright under Network Environment. Journal of Jiangxi Radio \& TV University, 33-35.

Li, Zhiyan. (2003, July). Analysis of Copyright Collective Management System. Public Administration \& Law, 22.

Luo, Xiangjing. (2009, September). Collective Management: an Intermediary of Information Technology and Copyright Protection. Hebei Law Science, 99-104.

Retrieved September 10, 2008, from http: //cb.j sh. gov. cn/copyright/fg21. jsp

Wang, Jifa \& Li, Gexia. (2011, July). Copyright Collective Administration Organizations and the Dilemma of Copyright Protection. Journal of Yantai University (Philosophy and Social Science Edition), 24-31.

Wang, Ping. (2010, February). Analysis of Collective Management of copyright under the net-environment. Productivity Research, 117-118.

Note

Note 1. Mutual representation agreement means that collective management organizations from different countries sign the agreement and manage the copyrights of organizations from different countries on behalf of these organizations in the local country. 